\title{
PERLINDUNGAN HUKUM PARA PIHAK DALAM PEMBUATAN AKTA RUPS YANG DILAKSANAKAN MELALUI TELEKONFERENSI
}

Oleh:

\author{
I Nyoman Agus Trisnadiasa ${ }^{1}$
}

\begin{abstract}
Development of Internet technology makes it easy for businesses to do any business activities like buying and selling, even holding meetings via teleconferencing media. The Act-No. 40 in 2007 allows RUPS agreement based media teleconference. On the one handthisphenomen on be overlapping when referring in the regulations of notary, in which the parties are required to be physically present in front of Notary. Given these problems, it can be formulated several problems including; First, Substance RUPS how that can be done via teleconference?; and Second, How is the legal protection of the parties in the RUPS agreement held via teleconference?; This research method using the kind of normative study. Technical approach of legislation and legal concept analysis approach using law books related to the problems.
\end{abstract}

Keywords: Legal Protection, RUPS agreement, and Teleconferencing

\begin{abstract}
Abstrak
Perkembangan teknologi internet memberikan kemudahan bagi para pebisnis melalukan setiap kegiatan bisnis seperti jual beli, bahkan mengadakan rapatmelalui media telekonferensi.UU PT memungkinkan pembuatan akta RUPS dibuat berdasarkan media telekonferensi.Di satu sisi fenomena ini menjadi tumpah tindih jika mengacu pada peraturan jabatan Notaris, di mana para pihak diwajibkan untuk hadir secara fisik dihadapan pejabat umum pembuat akta dalam hal pembuatan akta perjanjian. Mengingat problematika tersebut, maka dapat dirumuskan beberapa masalah diantaranya; 1) Substansi RUPS bagaimana yang dapat dilakukan melalui telekonferensi?;2) Bagaimana perlindungan hukum para pihak dalam pembuatan akta RUPS yang dilaksanakan melalui telekonferensi?; Metode penelitian ini mempergunakan jenis penelitian normatif.Teknik pendekatan peraturan perundang-undangan dan pendekatan analisis konsep hukum dengan menggunakan literatur - literatur hukum yang terkait dengan permasalahan.
\end{abstract}

Kata Kunci: Akta RUPS, Perlindungan Hukum, dan Telekonferensi

\section{PENDAHULUAN}

\subsection{Latar Belakang}

Perkembangan

teknologi

berbasis media internet, kini bukan lagi hal yang baru di era globalisasi. Di era globalisasi, internet bahkan telah digunakan oleh berbagai kalangan pelajar, instansi, karyawan,

Mahasiswa Magister Ilmu Hukum Universitas Udayana, Denpasar, Bali, Alamat: Jl. Imam Bonjol No. 445 Denpasar, Bali, e-mail : trisna_secret89@yahoo.com 
bahkan dikalangan pebisnis.

Media komunikasi maya ini mampu menghubungkan kalangan masyarakat secara mudah, cepat, dan tanpa mengenal batas wilayah negara.

Penggunaan

teknologi

informasi media internet dalam sektor bisnis ekonomi telah melahirkan dampak yang signifikan terhadap perkembangan hukum di Indonesia khususnya di bidang Cyber Notary. Cyber Notary merupakan konsep pemanfaatan telekomunikasi dunia maya untuk membuat akta otentik oleh notaris dalam melaksanakan tugas profesinya seperti,tandatangan akta elektrik, digitalisasi dokumen, pelaksanaan Rapat Umum Pemegang Saham (RUPS) secara telekonferensi. Adanya Cyber Notary menuntut profesi notaris tidak hanya menguasai ilmunya di bidang kenotariatan namun juga fasih menguasai teknologi dalam penerapan Cyber Notary.

Cyber Notary dibentuk untuk mempermudah para pihak bertransaksi lintas wilayah, sehingga tidak ada masalah, apabila salah satu para pihak tidak datang, berdasarkan konsep Cyber Notary memberikan manfaat efesien terhadap para pihak. Misalnya, pemegang saham sedang berada di Australia, Cina ataupun Prancis, dapat melaksanakan RUPS dengan menggunakan media telekonferensi secara bersama - sama dengan para pemegang saham lainnya, disaksikan langsung oleh Notaris di Indonesia. Kehadiran fisik dari para pemegang saham dimungkinkan untuk tidak hadir namun dapat dianggap mengikuti RUPS dan hak suaranya tetap dihitung dalam quorum kehadiran. Demikian pula pada saat penanda-tanganan akta RUPS para pemegang saham yang keberadaannya di luar kehadiran fisik RUPS tersebut dapat menanda-tangani dokumen rapat secara elektronik.

Ketentuan Pasal 77 ayat 1 UU 40 Tahun 2007 tentang Perseroan Terbatas (selanjutnya disebut UUPT), pengaturan mengenai pengadaan RUPS secara telekonferensi dapat diselenggarakan melalui video konferensi, media telekonferensi, atau sarana media elektronik lainnya yang memungkinkan semua peserta RUPS saling menyaksikan dan mendengar secara langsung serta berpartisipasi dalam agenda rapat.

Kebutuhan

ekonomi akanketepatan dan kecepatan pada zaman era globalisasi menjadi urgensi yang harus diperhatikan. Namun hal ini, tidak sertamerta menghilangkan sifat otentik dari akta notaris. Konsep Cyber Notary masih terjadi permasalahan dalam pelaksanaannya. Persoalan normatif kewajiban pembuat akta perjanjian yang mengharuskan hadir secara fisik dan menandatangani akta perjanjian dihadapan penghadap dan saksi yang pada intinya diatur berdasarkan penjelasan ketentuan Pasal 16 ayat (1) huruf m UU No. 2 Tahun 2014 perubahan atas UU No. 30 tahun 2004 Jabatan Notaris (selanjutnya disebut UU JN) menyebabkan adanya norma hukum yang tumpang tindih dalam 
pelaksanaan Cyber Notary terkait dengan penyelenggaraan RUPS yang diatur dalam ketentuan Pasal 76, 77, 78, UUPT. Selain adanya persoalan kontradiktif secara normatif diatas, adanya kekosongan hukum berkaitan dengan pelaksanaan substansi RUPS yang yang dapat dilakukan secara telekonferensi. Ketentuan Pasal 78 ayat (1) UUPT yang menyatakan bahwa Rapat Umum Pemegang Saham terdiri atas RUPS tahunan dan RUPS lainnya.Istilah "RUPS lainnya" dalam praktik disebut sebagai RUPS luar biasa. Penjelasan Pasal 78 juga tidak menjelaskan secara spesifik substansi RUPS seperti apa yang dapat dilakukan secara telekonferensi.

Berdasarkan uraian pemaparan latar belakang diatas, penulis menarik topik judul penelitian "Perlindungan

\section{Hukum Para Pihak Dalam} Pembuatan Akta RUPS Melalui Telekonferensi"

\subsection{Perumusan Masalah.}

Adapun rumusan masalah yang dapat penulis berikan terkait dengan penelitian ini :

1. Substansi RUPS bagaimana yang dapat dilakukan melalui telekonferensi ?

2. Bagaimana perlindungan hukum para pihak dalam pembuatan akta RUPS yang dilaksanakan melalui telekonferensi?

\subsection{Tujuan Penelitian}

\section{a. Tujuan umum}

Tujuan penulis yakni mengembangkan khasanah ilmu hukum terkait dengan perkembangan telekomunikasi yang semakin pesat.

\section{b. Tujuan Khusus}

Adapun tujuan penulis yakni terfokus mendeskripsikan dan analisis secara komprehensif tentang substansi RUPS yang dapat dilakukan melalui telekonferensi dalam penerapan Cyber Notary.

Untuk mengetahui perlindungan hukum para pihak dalam pembuatan akta RUPS yang dilaksanakan melalui telekonferensi

\section{METODE PENELITIAN}

Penelitian merupakan suatu kegiatan yang menghasilkan, mengembangkan dan menguji kelayakan suatu pengetahuan yang dilakukan secara berpola dengan sistem metodelogi dan sistematis. Disatu sisi yang dimaksud dengan metodelogi yakni penggunaan metode-metode yang sifatnya ilmiah, sedangkan penelitian yang sifatnyasistematis yakni sesuai dengan arahan pedoman/ aturan penelitian yang berlaku untuk karya ilmiah. ${ }^{2}$ Penelitian karya ilmiah ini bagian dari penelitian hukum normatif. Penelitian ini menggunakan teknis pendekatan peraturan perundang-undangan dan pendekatan

SutrisnoHadi, 2002, Metodelogi Research, SinarGrafika, Jakarta, hlm. 4. 
analisis konsep hukum. ${ }^{3}$ Penelitianini meneliti berbagai pengaturan hukum yang memfokuskan tema sentral suatu penelitian. Penelitiharus melihat hukum sebagai sistem tertutup yang mempunyai sifat-sifat seperti comprehensive, all-inclussive, systematic. ${ }^{4}$ Sedangkan Pendekatan analisis konsep hukum adalah analisis berbagai bahan hukum untuk mengetahui makna yang terkandung oleh istilah-istilah yang digunakan dalam aturan perundang-undangan secara konsepsional. Terdapat 2 teknik dalam melakukan pendekatan konseptual: Pertama, sang penulis berusaha memperoleh makna baru yang terkandung dalam aturan hukum yang bersangkutan. Kedua, menguji istilah-istilah hukum tersebut dalam praktik melalui analisis terhadap putusan pengadilan. $^{5}$

Literatur hukum yang dipergunakan seperti literatur primer yakni UU PT, dan UUJN beserta literatur hukum sekunder seperti buku, jurnal, karya tulis atau pandangan ahli terkait dengan khasanah hukum yang juga termuat dalam media masa, literatur hukum tersier berupa internet.

Pada teknik pengumpulan bahan hukum dilaksanakan dengan meneliti berbagai sumber bahan hukum yang ada kaitan dengan materi

\footnotetext{
H. Zainudin Ali, 2010, Metode Penelitian Hukum, Sinar Grafika, Jakarta, hlm. 24

4 Jhony Ibrahim, 2005, Teori \& Metodelogi Penelitian Hukum Normatif, Banyumedia, Surabaya, hlm. 302 Ibid
}

dibahas peneliti, selanjutnya akan dianalisis secara deskriptif analisis. ${ }^{6}$ Pada tahap penelitian analisis bahan hukum ini menggunakan teknik deskripsi dan teknik penemuan hukum (Rechtsvinding) ada tiga yakni analogi, Argumentum a contrario, Rechtsverfijning atau penghalusan hukum. $^{7}$

\section{HASIL DAN PEMBAHASAN \\ 3.1. Analisis Substansi RUPS Yang Dilaksanakan Secara Telekonferensi}

Berkembangnya teknologi infor-masi dan telekomunikasi melalui internet belakangan ini menyebabkan banyak transaksi yang dilakukan secara elektronik dengan menggunakan data digital sebagai pengganti kertas. Sama dengan transaksi pada umumnya yang menggunakan kertas, dokumen untuk bertransaksi beserta ditandatangani oleh dan/atau untuk dan atas nama pihak yang melakukan transaksi dengan tujuan bahwa dokumen tersebut benar-benar berasal dari dan telah disetujui oleh orang yang membubuhkan tandatangan tersebut. Dokumen elektronik nantinya pun akan ditandatangani secara elektronik. Digital signature merupakan alat untuk mengidentifikasikan suatu pesan yang diberikan. Digital signature dibutuhkan untuk:

\footnotetext{
H. Zainuddin Ali, op.cit, hlm. 107

I Dewa Gede Atmadja, 2009, Pengantar Penalaran dan Argumentasi Hukum (Legal Reasoning And Legal Argumentation) An Introdutcion, Bali Aga, Denpasar, hlm. 48
} 
1. Menentukan

identitassi pengirim;

2. Memastikan tidak ada perubahan isi pesan pada saat proses transmisi;

3. Memberikan kepastian kepada pengirim agar tidak ada penyangkal dikemudian hari.

Pelaksanaan Cyber Notary dalam RUPS secara telekonferensi dengan diberlakukannya UUPT masih terdapat persoalan hukum dalam pelaksanaannya yakni adanya kekosongan hukum terkait dengan substansi RUPS yang dapat dilaksanakan secara telekonferensi. Ketentuan UU PT pada Pasal 78 ayat (1) menyatakan bahwa Rapat Umum Pemegang Saham terdiri atas RUPS tahunan dan RUPS lainnya. Istilah "RUPS lainnya" dalam praktik disebut sebagai RUPS luarbiasa.Penjelasan Pasal 78 juga tidak menjelaskan secara spesifik substansi RUPS seperti apa yang dapat dilakukan secara telekonferensi dan bagaimana akibat hukumnya apabila substansi tersebut menimbulkan kerugian bagi pihak ke ketiga. Adanya kekosongan hukum dalam hal substansi RUPS yang dapat dilakukan secara telekonferensi tentunya akan berdampak pada kepastian hukum.

Pengertian Teori Kepastian hukum menguraikan 2 (dua) arti, Pertama adanya norma-norma umum yang membuat setiap orang mengetahui perbuatan yang tidak diperbolehkan atau diperbolehkan, Kedua adanya perlindungan hukum bagi individu dari kesewenang-wenangan pemerintah. Kepastian hukum tidak hanya berupa peraturan konkrit melainkan juga adanya konsistensi putusan hakim terdahulu dengan putusan hakim yang berlaku saat ini. $^{8}$

Berdasarkan teori kepastian hukum dalam kaitannya dengan jenis substansi RUPS yang dapat dilaksanakan secara telekonferensi UU PT hendaknya memberikan batasan yang tegas tentang substansi RUPS yang dapat dilaksanakan melalui telekonferensi. Dengan adanya penjelasan yang tegas tentang substansi RUPS yang dapat dilaksanakan secara telekonferensi memberikan individu pengetahuantentang pelaksanaan perbuatanserta memberikan keamanan bagi para pihak dari kesewenangan pemerintah.

Akta yang dibuat oleh notaris merupakan akta yang bersifat tindakan otentikbaik dilihat ataupun disaksikan oleh notaris sendiri didalam menjalankan jabatannya. Sebagai contohnya adalah Akta berita acara rapat sebuah PT, termasuk acara rapat secara Telekonferensi

Berdasarkan golongan akta yang dibuat oleh notaris, terdapat dua jenis, yakni (1) akta relaas atau berita acara, (2) Akta Pihak atau Akta Partij.

1. Akta Relaas dalam pembuatannya karakteristiknya adalah diuraikan sebagai berikut, yaitu:

Peter Mahmud Marzuki, 2008, Pengantar Ilmu Hukum, Kencana Pranada Media Group, Jakarta, hlm.158 
a. Sehubungan notaris sebagai pejabat umum, notaris bertugas untuk memuat keteranganketerangan yang disaksikan berdasarkan semua yang dialami dandilihatnya suatu perbuatan dari para pihak dalam pembuatan akta;

b. Apabila para pihak tidak menandatangani akta, keaslian akta tidak akan hilang;

c. Tidak dapat digugat, kecuali isi akta tersebut palsu.

2. Akta Partij dalam pembuatan karakteristiknya diuraikan sebagai berikut :

a. Memuat keterangan para pihak

b. Kewajiban adanya tanda tangan para pihak

c. Muatan isi dalam akta dapat digugat.

Permintaan kedua golongan akta diatas, akan diproses oleh Notaris apabila para pihak/penghadap memohon untuk dibuatkan perjanjian yang memikat berupa akta.

Akta Relaas merupakan akta dibuat berdasarkan permintaan para pihak yang dicatat dan ditulis oleh Notaris berkaitan dengan tindakan hukum ataupun tindakan lainnya, kemudian dituangkan dalam bentuk perjanjian otentik (akta Notaris). ${ }^{9}$ Perihal Notaris mencatat atau

Habib Adjie, 2008, Hukum Notaris Indonesia Tafsir Tematik terhadap UU No. 30 Tahun 2004, Refika Aditama, Bandung, (selanjutnya disebut Habib Adjie I) hlm. 45. menuliskan semua ketentuan peristiwa hukum dan/atau bukan peristiwa hukum yang disaksikan dan didengar sendiri secara langsung atas permintaan kehendak para pihak merupakan akta otentik yang menjelaskan suatu tindakan yang dilakukan atau suatu peristiwa yang disaksikan dan didengarkan oleh Notaris

Berdasarkan jenis-jenis akta tersebut, maka akta RUPS Telekonferensi termasuk dalam jenis akta relaas dan berdasarkan ketentuan akta relaas, maka keterangan Notaris dalam bentuk akta RUPS yang dibuat secara telekonferensi dapat dipastikan keabsahannya walaupun para pihak tidak membubuhkan tandatangannya pada akta tetapi Notaris yang membuat berita acaranya menjadi sebuah akta otentik dan memiliki kekuatan pembuktian yang sempurna.

Akta Relaas memuat uraian peristiwa yang disaksikan dan dilihatoleh Notaris sendiri (melalui media video call) atas permintaan para pihak yang bersangkutan dan dituliskandalam bentuk akta Notaris. ${ }^{10}$ Hal ini berbeda dengan Pernyataan Keputusan Rapat (PKR merupakan Partij Akta) sehingga akta tersebut dibuat dihadapan Notaris, dan memerlukan tandatangan para pihak untuk menuangkannya kedalam akta. (biasanya dikuasakan kepada salah seorang peserta RUPS).

Habib Adjie, 2009, Meneropong Khazanah Notaris dan PPAT Indonesia (Kumpulan Tulisan tentang Notaris dan PPAT), Citra Aditya Bakti, Bandung, (Selanjutnya disebut Habib Adjie II) hlm. 33. 
RUPS yang menggunakan telekonferensi adalah RUPS yang pada umumnya dihadiri oleh Notaris, sehingga dalam pelaksanaannya yang membuat Akta Berita Acara adalah Notaris, sehingga tanda tangan para pihak tidak wajib disertakan. Dalam kaitannya dengan akta Relaas, yang bertanggung jawab atas diterbitkannya akta tersebut adalah Notaris pembuat akta tersebut, sehingga syarat utamanya Notaris yang bersangkutan harus menghadiri RUPS dengan telekonferensitersebut, iamenyaksikan jalannya rapat, dan menuangkan jalannya rapat tersebut dalam sebuah Akta yang dikenal dengan berita acara RUPS.

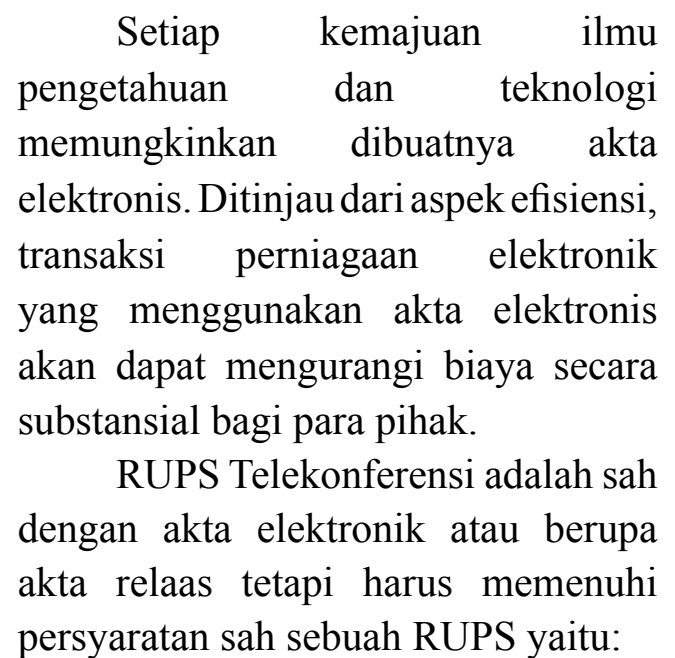

1. Kedudukan tempat Perseroan.

2. Pemanggilan para pemegang saham secara tertulis

3. Pemanggilan RUPS paling lambat 14 (empat belas) hari sebelum tanggal RUPS diadakan dengan tidak memperhitungkan tanggal panggilan dan tanggal RUPS diadakan.

4. Pemanggilan RUPS tidak diperlukan dalam hal semua pemegang saham hadir dan semua menyetujui agenda rapat dan keputusan disetujui dengan suara bulat.

5. Direktur Utama memimpin RUPS.

6. Apabila Direktur Utama berhalangan hadir dalam RUPS dipimpin oleh salah satu anggota Direksi.

7. Apabila semua Direktur berhalangan hadir dan/atau tidak perlu dibuktikan kepada pihak ketiga, RUPS dipimpin oleh salah seorang anggota Dewan Komisaris.

8. Apabila semua anggota Dewan Komisaris berhalangan dan/atau tidak perlu dibuktikan kepada pihak ketiga, RUPS dipimpin oleh seorang yang dipilih oleh dan di antara mereka yang hadir dalam RUPS.

Namun perlu diperhatikan disiniadalah bahwa Notaris harus wajib menyaksikan sendiri jalannya RUPS secara telekonferensi tersebut, bukan dengan membuat Pernyataan Keputusan Rapat (PKR) atau Berita Acara RUPS berdasarkan RUPS dibawah tangan dengan tandatangan yang discan. Selama tidak ada suatu program software yang dapat mengintegrasikan audio, visual dan dokumen yang dapat ditandatangani secara elektronik, maka sebelum dibuatkan Akta Pernyataan Keputusan RUPS harus dibuktikan lebih dahulu bahwa apa yang dibicarakan dalam 
rapat adalah benar-benar sama dengan yang tercantum dalam Notulen Rapat.

\subsection{Perlindungan Hukum Para Pihak Dalam Pembuatan Akta RUPS yang Dilaksanakan Melalui Telekonferensi}

RUPS diselenggarakan dengan melibatkan berbagai pihak yang diantaranya meliputi Organ Perseroan dan Notaris. Sehubungan dengan hal tersebut, maka wajar apabila perlindungan hukum bagi para pihak tersebut juga menjadi fokus perhatian.

Dimensi perlindungan terhadap individu setiap orang salah satunya berbentuk perlindungan hukum. Hukum mempunyai fungsi melindungi hakekat dan martabat individu setiap orang.Adanya perlindungan hukum terhadap warga Indonesia diatur dalam ketentuan peraturan hukum tertinggi yakni Undang-undang Dasar NRI 1945 (UUD NRI 1945), sehingga setiap produk peraturan yang dibuat oleh pemerintah wajib memberikan perlindungan hukum. Menurut pendapat Satipto Rahardjo, perlindungan hukum adalah segala upaya untuk melindungi kepentingan subyek hukum dengan cara mengalokasikan suatu kekuasaan kepadanya untuk melaksanakan kepentingannya tersebut. ${ }^{11}$

Selanjutnya, Philipus M. Hadjo memberikan pandangan bahwa makna perlindungan hukum merupakan

Satjipto Rahardjo, 2003, Sisi-sisi lain dari hukum di Indonesia, Kompas, Jakarta, hlm. 121. tindakan melindungi subyek hukum dengan pranata-pranata hukum. ${ }^{12}$

Munculnya perlindungan hukum yang diberikan oleh negara terhadap masyarakat dibuat dalam bentuk ketentuan peraturan perundangundangan sebagai bentuk jaminan kepastian hukum dari tindakan kesewenang-wenangan pejabat dalam menjalankan tugasnya yang menimbulkan kerugian bagi para pihak. Pejabat wajib memberikan tanggung jawab atas kelalaiannya. Berdasarkan pendapat Kranenburg dan Vegtig, teori pertanggungjawaban dapat dibagi menjadi 2 (dua) persoalan pertanggungjawaban pejabat terhadap penyalahgunaan wewenang yaitu:

a. Teori fautespersonalles mengurai-kan ketentuan bahwa pemberian ganti rugi terhadap pihak ketiga dibebankan kepada pejabat yang karena tindakannya itu telah menimbulkan kerugian. Dalam teori ini beban tanggung jawab ditujukan pada manusia selaku pribadi. ${ }^{13}$

b. Teorifautes de services, memuat ketentuan bahwa pemberian ganti rugi pihak ketiga dibebankan pada instansi dari pejabat yang bersangkutan. Penerapannya, kerugian yang timbul disesuaikan dengan kesalahan baik kesalahan ringan atau kesalahan berat

\footnotetext{
12 Philipus M. Hadjon, dkk, 2011, Pengantar Hukum Administrasi Indonesia, Gajah Mada University Press, Yogyakarta, hlm.10

13 Ridwan H.R, 2008, Hukum Administrasi Negara, Rajawali Pers, Jakarta, hlm. 365
} 
berimplikasi pada tanggung jawab yang harus ditanggung. ${ }^{14}$

Notaris dalam menjalankan jabatannya pada pelaksanaan RUPS produk aktanya menimbulkan kerugian berdasarkan teori pertanggungjawaban hukum ia dapat dimintai pertanggungjawaban atas perbuatannya yang menyebabkan kerugian yang disebabkan oleh jabatannya atau secara pribadi. Apabila Organ Perseroan Terbatas (PT) dalam pelaksanaan RUPS menyebabkan kerugian bagi Notaris dalam hal ini Notaris dapat mengajukan gugatan ganti rugi berdasarkan ketentuan Pasal 1365 KUH Perdata pada intinya adanya perbuatan melawan hukum, kesalahan para pelaku, kerugian pihak korban, dan hubungan kausal perbuatan dengan kerugian.

Perlindungan hukum bagi notaris dalam pembuatan akta RUPS yang dilaksanakan melalui telekonferensi pada hakekatnya sama dengan perlindungan hukum bagi Notaris yang melakukan kewenangannya secara umum. Perlindungan hukum bagi Notaris ditentukan berdasarkan Pasal 66 UUJN.

Perlindungan hukum bagi organ perseroan sehubungan dengan pembuatan Akta RUPS yang dilaksanakan melalui telekonferensi apabila kemudian hari timbul sengketa dapat meliputi dua hal, antara lain :
1. Melalui gugatan perdata yang diajukan ke pengadilan sesuai dengan PT tersebut berdomisili/berkedudukan (dihubungkan dengan pasal 1365 KUHPerdata);

2. Melapor atau memberi pengaduan ke Majelis Pengawas Wilayah Notaris sesuai dengan kewenangan Majelis Pengawas Wilayah pada Pasal 73 UUJN.

\section{PENUTUP}

\subsection{Simpulan}

1. Pengaturan substansi RUPS berdasarkan ketentuan UU Perseroan Terbatas, tidak menjelaskan secara tegas tentang dilaksanakannya RUPS secara telekonferensi. Pembuatan akta RUPSyang dilaksanakan melalui telekonferensi oleh Notaris adalah sah sepanjang memenuhi persyaratan pelaksanaan RUPS.

2. Penyelenggaraan RUPS terdiri dari berbagai pihak diantaranya meliputi Organ Perseroan dan Notaris. Perlindungan hukum bagi Notaris diatur berdasarkan ketentuan pasal 66 UndangUndang No 2 tahun 2014 tentang Jabatan Notaris (UUJN). Sedangkan Perlindungan hukum bagi organ perseroan sehubungan dengan pembuatan Akta RUPS yang dilaksanakan melalui telekonferensi apabila kemudian hari timbul sengketa meliputi dua hal, antara lain : 
a. Melalui gugatan perdata yang diajukan ke pengadilan sesuai dengan dimana PT itu berdomisili/berkedudukan (pasal 1365 KUHPerdata);

b. Melapor atau memberi pengaduan ke majelis pengawas wilayah Notaris sesuai dengan pasal 73 UUJN.

\subsection{Saran}

1. Disarankan kepada Pemerintah untuk membentuk peraturan pelaksanaan UUPT terkait dengan pengaturan substansi RUPS yang dapat dilaksanakan melalui telekonferensi dalam Cyber Notary guna menjamin adanya kepastian hukum.

2. Diharapkan pemerintah memformulasikan kebijakan tentang perlindungan hukum terhadap Cyber Notary, sehingga pemanfaatan teknologi informasi dalam tugas Notaris sebagai pejabat umum memiliki nilai kepastian hukum yang keabsahannya dapat dipastikan.

\section{DAFTAR PUSTAKA}

Habib Adjie, 2008, Hukum Notaris Indonesia Tafsir Tematik terhadap UUNo. 30 Tahun 2004, Refika Aditama, Bandung. , 2009, Meneropong Khazanah Notaris dan PPAT Indonesia (Kumpulan Tulisan tentang Notaris dan PPAT), Citra Aditya Bakti, Bandung.
H. Zainudin Ali, 2010, Metode Penelitian Hukum, Sinar Grafika, Jakarta.

I Dewa Gede Atmadja, 2009, Pengantar Penalaran dan Argumentasi Hukum (Legal Reasoning And Legal Argumentation) An Introdutcion, Bali Aga, Denpasar.

Jhony Ibrahim, 2005, Teori \& Metodelogi Penelitian Hukum Normatif, Banyumedia, Surabaya.

M. Iqbal Hasan, 2002, Pokok-Pokok Materi Metode Penelitian Dan Aplikasinya, Cet. I, Ghalia Indonesia, Jakarta.

Peter Mahmud Marzuki, 2008, Pengantar Ilmu Hukum, Kencana Pranada Media Group, Jakarta.

Philipus M. Hadjon, dkk, 2011, Pengantar Hukum Administrasi Indonesia, Gajah Mada University Press, Yogyakarta.

Ridwan H.R, 2008, Hukum Administrasi Negara, Rajawali Pers, Jakarta.

SatjiptoRahardjo, 2003, Sisi - sisi Lain Dari Hukum di Indonesia, Kompas, Jakarta

Sutrisno Hadi, 2002, Metodologi Research, Sinar Grafika, Jakarta. 